\title{
Antimalarial Activity of Some Organotin(IV) Chlorobenzoate Compounds against Plasmodium falciparum
}

\author{
Sutopo Hadi *, Mona Dwi Fenska, Rama Aji Wijaya, Noviany and Tati Suhartati \\ Department of Chemistry, Faculty of Mathematics and Natural Sciences, \\ University of Lampung, Bandar Lampung, Indonesia 35145
}

\begin{abstract}
This paper reported the comparative study on antimalarial activity of some organotin(IV) derivatives with some chlorobenzoic acid derivatives used as the ligands. The compounds were synthesized by reacting the intermediate products of dibutyltin(IV) oxide, diphenyltin(IV) dihydroxide and triphenyltin(IV) hydroxide, with chlorobenzoic acid. The antimalarial activity was performed against Plasmodium falciparum. The results showed that the $\mathrm{IC}_{50}$ of the compounds tested were about the same with the chloroquine $\left(2 \times 10^{-3} \mu \mathrm{g} / \mathrm{mL}\right)$ used as the positive control, but unlike chloroquine which has been known to have resistance as antimalarial, these organotin(IV) compounds prepared are not resistant to the Plasmodium. The result also showed that the derivative of triphenyltin(IV) has higher $\mathrm{IC}_{50}$ respective to others.
\end{abstract}

Keywords: antimalarial activity; comparative study; $\mathrm{IC}_{50}$; organotin(IV) chlorobenzoate; P. Falciparum.

\section{Introduction}

Malaria, a disease caused by Plasmodium, has been known since a century ago and continues to be a significant public health problem in Indonesia and other tropical countries. Due to the broader effect caused by malaria, WHO pays attention to this disease by a program called Roll Back Malaria(RBM) where a few points of this program were immediate diagnoses and specific treatment to eradicate malaria ${ }^{1-3}$. The malaria cases in Indonesia between the periods of 1997 - 2001 increased sharply, including in the Provinces of Java and Bali by ten times, while outside these Provinces were increased 4-5 times. These cases were also followed by resistance cases toward standard drugs used in the malaria treatments, the chloroquine and the sulfadoxine-pyrimethamine. In some provinces, there were more than $25 \%$ resistance cases which cause the use of these standard drugs to be much more limited; therefore efforts to find new potent antimalarial drugs are urgently required ${ }^{3}$.

The organotin(IV) compounds continue to attract many chemists because of their strong effect in many biological tests ${ }^{4,5}$. The critical factor affecting their biological activities is determined by the organic type groups present in $\mathrm{Sn}$ atom ${ }^{6}$, whereas the nature of the anionic groups present is only as a secondary factor ${ }^{7}$. The investigations on the coordination of carboxylates and their derivatives into organotin compounds have led to the isolation of some new organotin(IV) carboxylates, and carboxylate derivatives which have shown some engaging biological activities such as antitumor and anticancer ${ }^{8-11}$, antimicrobial 9-12, antifungal activity ${ }^{6,12,13}$, anticorrosion inhibitor ${ }^{14-17}$, antiplasmodial ${ }^{18,19}$ and the latest development of these compounds has led the new finding as antimalarial; therefore the investigation of organotin(IV) as possible antimalarial is still very challenging, and therefore have attracted much attention ${ }^{18,19}$.

Based on the fact that organotin(IV) compounds have been found to have a promising result as an antimalarial activity, in this paper, we reported the application and antimalarial activity study of some organotin(IV) benzoate against $P$. falciparum.

\section{Results and Discussion}

The syntheses of organotin(IV) chlorobenzoate have successfully been prepared following the previous results. In this work, we synthesized three organotin(IV) chlorobenzoates of dibutyltin(IV) dichlorobenzoate, $\left[\left(n-\mathrm{C}_{4} \mathrm{H}_{9}\right)_{2} \mathrm{Sn}\left(\mathrm{OOCC}_{6} \mathrm{H}_{4} \mathrm{Cl}\right)_{2}\right]$ (3), diphenyltin(IV)dichlorobenzoate $\left[\left(\mathrm{C}_{6} \mathrm{H}_{5}\right)_{2} \mathrm{Sn}\left(\mathrm{OOCC}_{6}\right.\right.$ $\left.\mathrm{H}_{4} \mathrm{Cl}\right)_{2}$ ] (6) and triphenyltin(IV) chlorobenzoate, $\left[\left(\mathrm{C}_{6} \mathrm{H}_{5}\right)_{3} \mathrm{Sn}\left(\mathrm{OOCC}_{6} \mathrm{H}_{4} \mathrm{Cl}\right)\right](9)$, from their chlorides $\left[\left(n-\mathrm{C}_{4} \mathrm{H}_{9}\right)_{2} \mathrm{SnCl}_{2}\right] \quad(\mathbf{1}), \quad\left[\left(\mathrm{C}_{6} \mathrm{H}_{5}\right)_{2} \mathrm{SnCl}_{2}\right] \quad$ (4) and $\left[\left(\mathrm{C}_{6} \mathrm{H}_{5}\right)_{3} \mathrm{SnCl}\right](7)$, respectively, where these reactions were conducted via $\left[\left(n-\mathrm{C}_{4} \mathrm{H}_{9}\right)_{2} \mathrm{SnO}\right]$ (2), $\left[\left(\mathrm{C}_{6} \mathrm{H}_{5}\right)_{2} \mathrm{Sn}(\mathrm{OH})_{2}\right] \quad$ (5) and $\left[\left(\mathrm{C}_{6} \mathrm{H}_{5}\right)_{3} \mathrm{SnOH}\right] \quad$ (8) respectively similar to the known procedure used 10-13, 16-18. The data of microanalysis for the compounds synthesized are tabulated in Table 1, 
where all values obtained are excellent and are close to the calculated values.

Some spectroscopy techniques have been applied to identify the compounds synthesized. The assignments of relevant FT-IR data are shown in Table 2. The presence of strong stretching band at $390-310 \mathrm{~cm}^{-1}$ is a characteristic band of $\mathrm{Sn}-\mathrm{Cl}$ bond for starting materials $(\mathbf{1}, \mathbf{4}, 7)$. The $\mathrm{Sn}-\mathrm{Cl}$ bond in $\mathbf{1}$, for instance, occurred in the frequency of $334.2 \mathrm{~cm}^{-1}$. The other characteristic bands of this compound for butyl ligands as expected appeared as a stretching band at $1069 \mathrm{~cm}^{-1}$, and bending vibration of $\mathrm{C}-\mathrm{H}$ aliphatic stretch of the butyl at the frequency of $2956-2865 \mathrm{~cm}^{-1}$. Once compound $\mathbf{1}$ is converted to $\mathbf{2}$, the presence of the main stretching band for $\mathrm{Sn}-\mathrm{Cl}$ diminished, while a new strong band at frequency of $417.4 \mathrm{~cm}^{-1}$ present as one of the main stretching bands. This band is characteristic for $\mathrm{Sn}-\mathrm{O}$ bond in compound 2.

Table 1. The microanalytical data of the organotin(IV) compounds synthesized.

\begin{tabular}{|c|c|c|}
\hline \multirow{2}{*}{ Compound } & \multicolumn{2}{|c|}{ Elemental analysis found (calculated) } \\
\hline & $\mathbf{C}$ & $\mathbf{H}$ \\
\hline$\left[\left(n-\mathrm{C}_{4} \mathrm{H}_{9}\right)_{2} \mathrm{SnCl}_{2}\right](\mathbf{1})$ & $31.4(31.6)$ & $6.0(5.9)$ \\
\hline$\left[\left(n-\mathrm{C}_{4} \mathrm{H}_{9}\right)_{2} \mathrm{SnO}\right](2)$ & $38.6(38.6)$ & $7.1(7.3)$ \\
\hline$\left[\left(n-\mathrm{C}_{4} \mathrm{H}_{9}\right)_{2} \mathrm{Sn}\left(\mathrm{OOCC}_{6} \mathrm{H}_{4} \mathrm{Cl}\right)_{2}\right]$ & $46.8(46.7)$ & $4.7(4.6)$ \\
\hline$\left[\left(\mathrm{C}_{6} \mathrm{H}_{5}\right)_{2} \mathrm{SnCl}_{2}\right](4)$ & $41.7(41.9)$ & $2.8(2.9)$ \\
\hline$\left[\left(\mathrm{C}_{6} \mathrm{H}_{5}\right)_{2} \mathrm{Sn}(\mathrm{OH})_{2}\right](5)$ & $46.5(46.9)$ & $3.8(3.9)$ \\
\hline$\left[\left(\mathrm{C}_{6} \mathrm{H}_{5}\right)_{2} \mathrm{Sn}\left(\mathrm{OOCC}_{6} \mathrm{H}_{4} \mathrm{Cl}\right)_{2}\right](6)$ & $51.3(51.6)$ & $3.1(2.98)$ \\
\hline$\left[\left(\mathrm{C}_{6} \mathrm{H}_{5}\right)_{3} \mathrm{SnCl}\right](7)$ & $55.8(56.1)$ & $4.0(3.9)$ \\
\hline$\left[\left(\mathrm{C}_{6} \mathrm{H}_{5}\right)_{3} \mathrm{Sn}(\mathrm{OH})\right](8)$ & $58.4(58.9)$ & $4.3(4.4)$ \\
\hline$\left[\left(\mathrm{C}_{6} \mathrm{H}_{5}\right)_{3} \mathrm{Sn}\left(2-\mathrm{OOCC}_{6} \mathrm{H}_{4} \mathrm{Cl}\right)\right]$ & $57.2(58.1)$ & $3.8(3.68)$ \\
\hline
\end{tabular}

The stretching band for butyls and their bending vibrations still appear as expected although the frequencies have been shifted. The formation of dibutyltin(IV) dichlorobenzoate compounds, $\left[\left(n-\mathrm{C}_{4} \mathrm{H}_{9}\right)_{2} \mathrm{Sn}\left(\mathrm{OOCC}_{6} \mathrm{H}_{4} \mathrm{Cl}\right)_{2}\right],(3)$ is confirmed by the strong asymmetric stretching bands of the carboxylate groups which is at ca. $1400 \mathrm{~cm}^{-1}$ and the symmetric stretch at ca. $1600 \mathrm{~cm}^{-1}$ and also supported by the present of Sn-O stretching of the acid at $435 \mathrm{~cm}^{-1}$, and the appearance of these bands is the critical success of the substitution reaction of $\mathbf{1}$ to $\mathbf{2}^{10-13,16-18,20}$.

The FT-IR spectra change in the formation of compound $\mathbf{9}$ from $\mathbf{7}$ and $\mathbf{8}$ are shown in Fig. 1.

Table 2. The characteristic and important IR bands of the organotin(IV) compounds $\left(\mathrm{cm}^{-1}\right)$ synthesized.

\begin{tabular}{|c|c|c|c|c|}
\hline Compound & $\mathbf{3}$ & $\mathbf{6}$ & $\mathbf{9}$ & References \\
\hline Sn-O & 434.4 & 594.0 & 735.42 & $\mathbf{8 0 0 - 4 0 0}$ \\
\hline Sn-O-C & 1029.1 & 1238.2 & 1243.4 & $\mathbf{1 0 5 0 - 9 0 0}$ \\
\hline Sn-Bu & 674.4 & - & - & $\mathbf{7 4 0 - 6 6 0}$ \\
\hline CO2asym & 1419.1 & 1531.7 & 1557.5 & $\mathbf{1 6 0 0 - 1 4 0 0}$ \\
\hline CO2Sym & 1558.1 & 1659.3 & 1630.4 & $\mathbf{1 7 0 0 - 1 5 5 0}$ \\
\hline C-H aliphatic & $2954-2860$ & - & - & $\mathbf{2 9 6 0}-\mathbf{2 8 5 0}$ \\
\hline Phenyl & - & $\mathbf{1 4 6 7 . 0} ; \mathbf{7 5 0 . 7}$ & $\mathbf{1 4 2 8 . 4 ;} \mathbf{7 2 9 . 1}$ & $\mathbf{1 4 5 0 , 7 3 0}$ \\
\hline
\end{tabular}



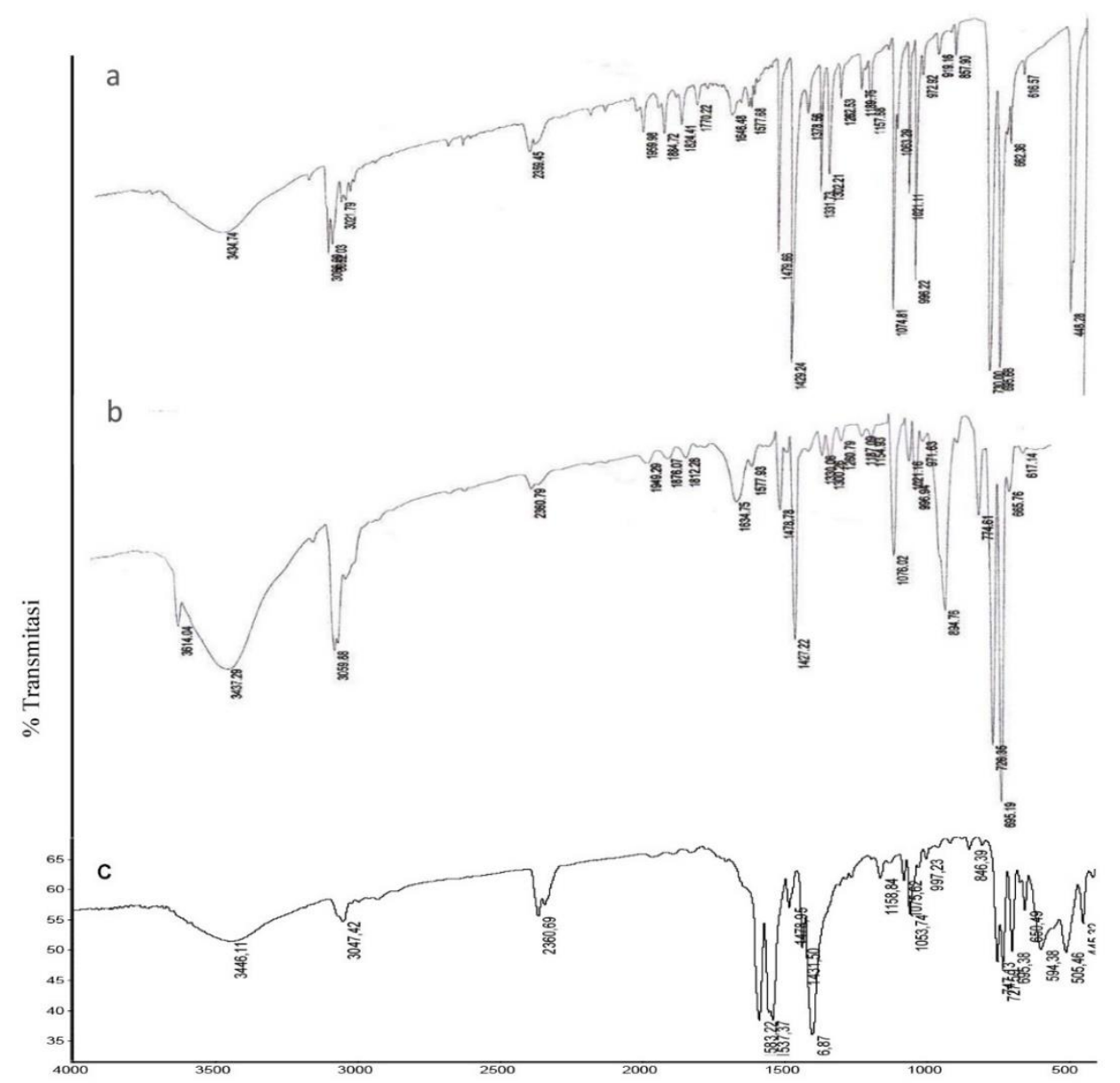

Figure 1. FT-IR spectra of (a) triphenyltin(IV) chloride (7); (b) triphenyltin(IV) hydroxide (8);

(c) triphenyltin(IV) 2-hydroxybenzoate (9)

The results of UV analyses for the compounds tested to obtain $\lambda_{\max }$ are shown in Table 3. From the data obtained, it is very clear the $\lambda_{\max }$ for each compound in any steps of the reaction has been changed. The compound 1 has $\lambda_{\max }$ of $210.7 \mathrm{~nm}$, while compound 2 has $\lambda_{\max }$ of $202.9 \mathrm{~nm}$, although the shift is not big, this information gave an indication that there was a shift to a shorter $\lambda_{\max }$ value when the conversion of compound 1 to 2 occurred. The wave-length shift to a shorter $\lambda_{\max }$ could happen because of either the solvent used in the measurement or the effect of an auxochrome of the ligand. However, in this study, as the solvent used for all measurements was the same (methanol), the change in the $\lambda_{\max }$ that occurred must be due to the auxochrome effect. In the case of compound $\mathbf{1}$ and $\mathbf{2}$, there is an oxide group which has electron drawing effect bigger in compound $\mathbf{2}$ than that of chloride group in $\mathbf{1}$; thus the electron transition in $\mathbf{2}$ is hard to occur. As a result, the measured $\lambda_{\max }$ was getting shorter in compound $\mathbf{2}$ than in compound $\mathbf{1}^{20-22}$. Similar results are also observed for other changes as can be seen from Table 3. For example, in compound $\mathbf{3}$, the electron drawing effect of $2-\mathrm{C}_{6} \mathrm{H}_{4} \mathrm{ClCOOH}$ is less than chloride in $\mathbf{1}$, so the electron transition in this molecule will be easier (the energy required is less), thus producing longer $\lambda_{\max }, 291.3 \mathrm{~nm}$.

Table 3. The $\lambda_{\max }$ of the UV-Vis spectra of the organotin(IV) chlorobenzoate compounds.

\begin{tabular}{|c|c|c|c|}
\hline \multirow[b]{2}{*}{ Compound } & \multicolumn{3}{|c|}{$\lambda_{\max }(\mathrm{nm})$} \\
\hline & $\pi-\pi^{*}$ & $\mathbf{n}-\boldsymbol{\pi}$ & $\begin{array}{c}\text { Benzene ring } \\
\text { secondary band }\end{array}$ \\
\hline$\left[\left(n-\mathrm{C}_{4} \mathrm{H}_{9}\right)_{2} \mathrm{SnCl}_{2}\right](\mathbf{1})$ & 210.7 & - & - \\
\hline$\left[\left(n-\mathrm{C}_{4} \mathrm{H}_{9}\right)_{2} \mathrm{SnO}\right](2)$ & 202.9 & - & - \\
\hline$\left[\left(n-\mathrm{C}_{4} \mathrm{H}_{9}\right)_{2} \mathrm{Sn}\left(\mathrm{OOCC}_{6} \mathrm{H}_{4} \mathrm{Cl}\right)_{2}\right](3)$ & - & 291.1 & - \\
\hline$\left[\left(\mathrm{C}_{6} \mathrm{H}_{5}\right)_{2} \mathrm{Sn}\left(\mathrm{OOCC}_{6} \mathrm{H}_{4} \mathrm{Cl}\right)_{2}\right](6)$ & 200.7 & 298.7 & 406.6 \\
\hline$\left.\left[\left(\mathrm{C}_{6} \mathrm{H}_{5}\right)_{3} \mathrm{Sn}\left(\mathrm{OOCC}_{6} \mathrm{H}_{4} \mathrm{Cl}\right)\right](9)\right)$ & 203.6 & 303.5 & 409.7 \\
\hline
\end{tabular}


Table 4. ${ }^{1} \mathrm{H}$ and ${ }^{13} \mathrm{C}$ spectra of the compounds synthesized.

\begin{tabular}{|c|c|c|c|}
\hline Compounds & $\begin{array}{l}\text { H in butyl or } \\
\text { phenyl (ppm) }\end{array}$ & $\begin{array}{l}\mathrm{H} \text { in } \\
\text { benzoate } \\
(\mathbf{p p m})\end{array}$ & $\begin{array}{c}\text { C in butyl, phenyl and } \\
\text { benzoate } \\
(\text { ppm) }\end{array}$ \\
\hline$\left[\left(n-\mathrm{C}_{4} \mathrm{H}_{9}\right)_{2} \mathrm{Sn}\left(\mathrm{OOCC}_{6} \mathrm{H}_{4} \mathrm{Cl}\right)_{2}\right](3)$ & $\begin{array}{c}\mathrm{H} \alpha \& \mathrm{H} \beta: 1.35- \\
1.60(\mathrm{~m}) ; \mathrm{H} \gamma: \\
1.27(\mathrm{~m}) ; \mathrm{H} \delta: \\
0.91(\mathrm{t})\end{array}$ & $\begin{array}{c}7.33-7.85 \\
(\mathrm{~m})\end{array}$ & $\begin{array}{c}\mathrm{C} \alpha: 21.0 ; \mathrm{C} \beta: 26.4 ; \mathrm{C} \gamma: 25.7 \\
\mathrm{C} \delta: 14.0 ; \mathrm{C} 1: 166.7 ; \mathrm{C} 2: \\
\text { 139.1; C3 \& C7: } 129.5 ; \mathrm{C} 4 \& \\
\text { C6: } 128.4 ; \mathrm{C} 5: 125.1\end{array}$ \\
\hline$\left[\left(\mathrm{C}_{6} \mathrm{H}_{5}\right)_{2} \mathrm{Sn}\left(\mathrm{OOCC}_{6} \mathrm{H}_{4} \mathrm{Cl}\right)_{2}\right](6)$ & $\begin{array}{c}\mathrm{H} 2 \text { \& H6 } 7.56 \\
(\mathrm{~d}, 4 \mathrm{H}) ; \mathrm{H} 3 \& \\
\mathrm{H} 57.45(\mathrm{t}, 4 \mathrm{H}) \\
\mathrm{H} 4: 7.32(\mathrm{t}, 2 \mathrm{H})\end{array}$ & $\begin{array}{c}7.78-7.91 \\
(\mathrm{~d})\end{array}$ & $\begin{array}{c}\text { C1-C6 (phen) } 129.3-128.8 ; \\
\text { C7 167.2; C8 136.7; C9 } \\
\text { 133.9; C10 129.9; C11 135.3; } \\
\text { C12 1267; C13 131.7 }\end{array}$ \\
\hline$\left.\left[\left(\mathrm{C}_{6} \mathrm{H}_{5}\right)_{3} \mathrm{Sn}\left(\mathrm{OOCC}_{6} \mathrm{H}_{4} \mathrm{Cl}\right)\right](9)\right)$ & $\begin{array}{c}\mathrm{H} 2 \text { \& H6 } 7.55 \\
(\mathrm{~d}, 6 \mathrm{H}) ; \mathrm{H} 3 \& \\
\text { H5 } 7.43(\mathrm{t}, 6 \mathrm{H}) \\
\mathrm{H} 4: 7.0(\mathrm{t}, 3 \mathrm{H})\end{array}$ & $\begin{array}{c}7.77-7.90 \\
(\mathrm{~d})\end{array}$ & $\begin{array}{c}\text { C1-6 (phen): 131.0-126.0; C7: } \\
\text { 167.1; C8: 139.0; C9 \& C13: } \\
\text { 130.0; C10 \& C12: 128.3; } \\
\text { C11: } 127.9\end{array}$ \\
\hline
\end{tabular}

The results of ${ }^{1} \mathrm{H}$ and ${ }^{13} \mathrm{C}$ NMR for the compounds synthesized are presented in Table 4, and the examples of spectra for compound $\mathbf{6}$ are shown in Fig. $2\left({ }^{1} \mathrm{H}\right.$ NMR) and Fig. $3\left({ }^{13} \mathrm{C}\right.$ NMR).

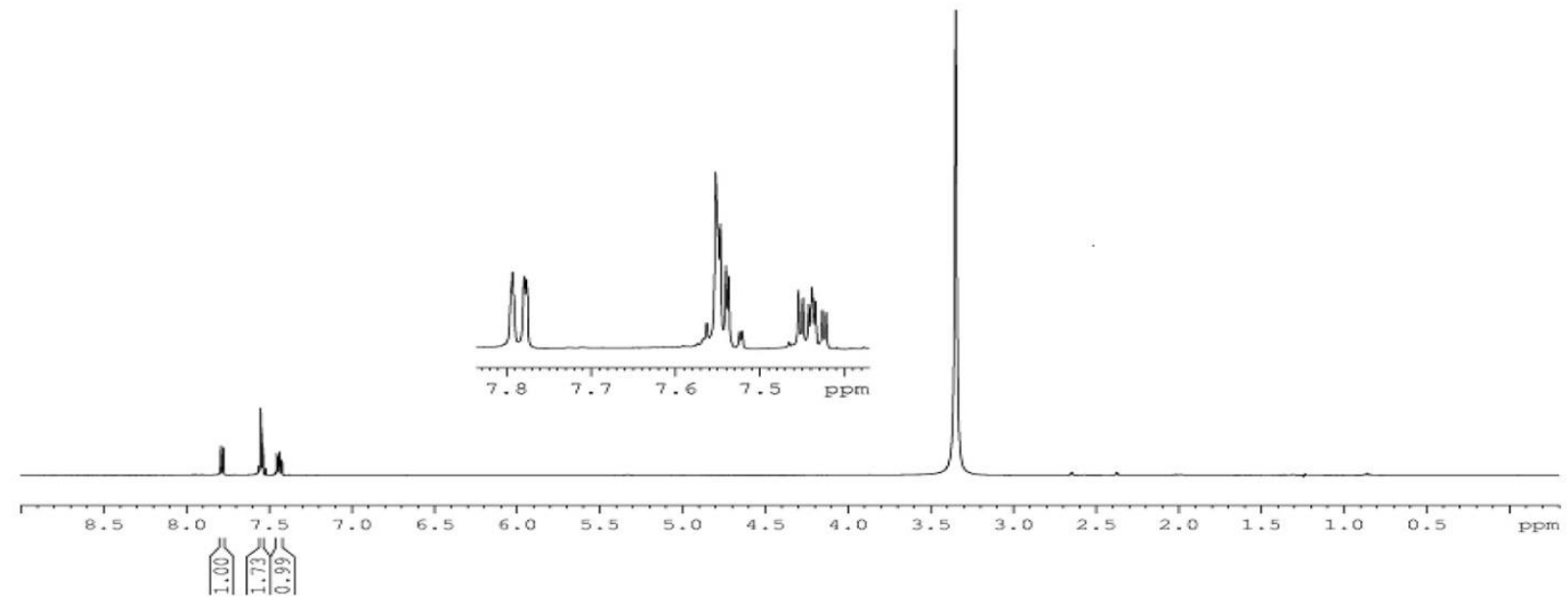

Figure 2. ${ }^{1} \mathrm{H}$ NMR spectrum of Compound 6
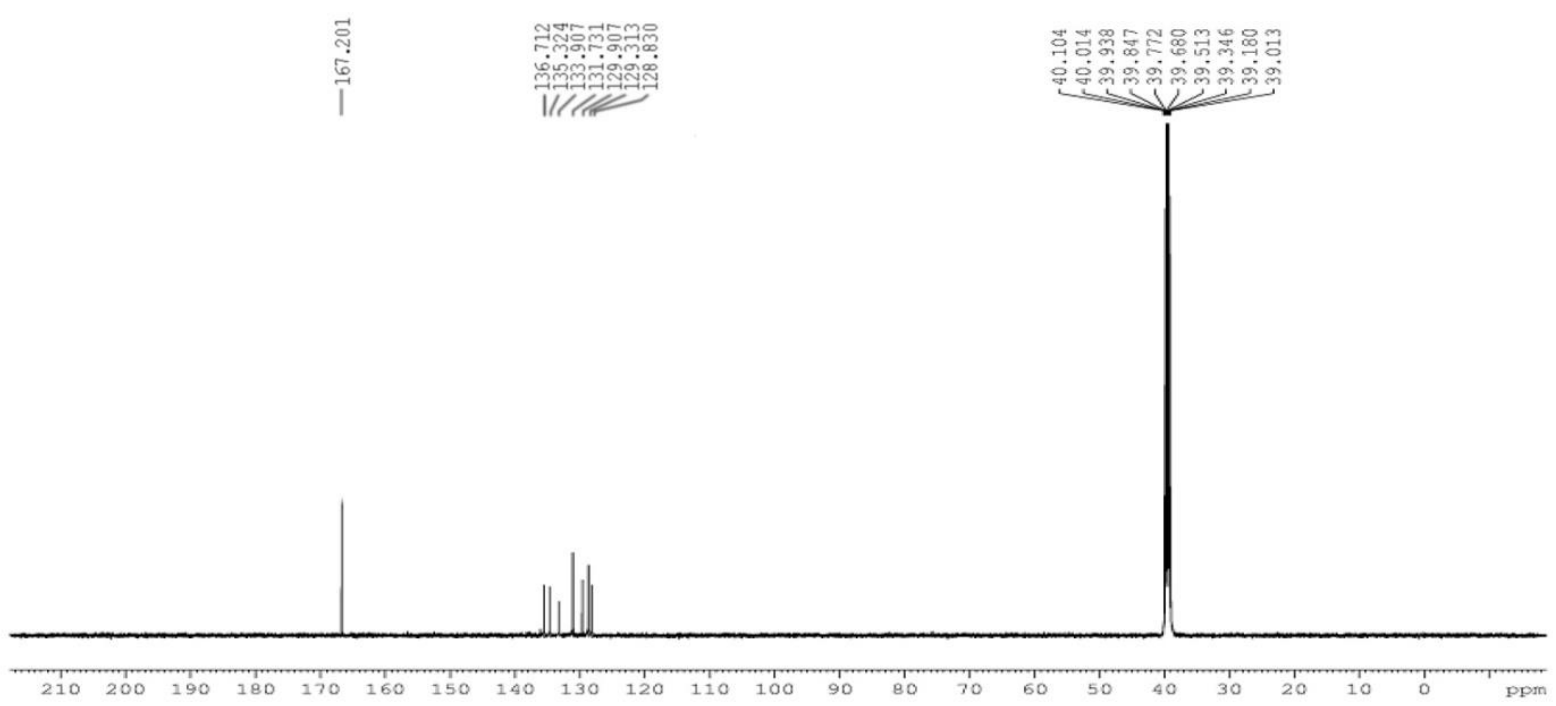

Figure 3. ${ }^{13} \mathrm{C}$ NMR spectrum of Compound 6 
Some important signals in the spectra obtained have been characterized carefully. The chemical shift $(\delta)$ of butyl protons attached to the tin metal appeared in the range of 0.91 ppm for $\mathrm{H} \delta$ up to 1.35-1.60 ppm for $\mathrm{H} \alpha$ and $H \beta$, and the carbons of butyl ligands are observed at position comparable with other similar compounds reported previously ${ }^{3,7,16-18,21,22}$. The chemical shift of phenyl protons attached to tin metal appeared in the range of $7.0-7.56 \mathrm{ppm}$, while the carbon of carboxyl group of all compounds as expected appeared in the region of $167 \mathrm{ppm}{ }^{3,7,16-18,21,22}$. The carbon atoms of the phenyl ligand as also expected appeared in $\delta$ of 131-126 ppm, while the carbons in the chlorobenzoate derivatives appeared in $\delta$ range of 140-130 ppm close to the reported values of similar compounds $3,7,16-18,21,22$.

We have previously reported the antifungal and anticancer activity of the compounds similar to those reported in this work ${ }^{10-13}$, and it is found that optimal activity of the antifungal and anticancer was related to the number of carbon atoms of the ligand present in the organotin(IV) used ${ }^{10-13,23 .}$

In general, the derivative of triphenyltin(IV) carboxylate, which contains 18 carbon atoms has the highest activity 10-13,23, and surprisingly same phenomena were also observed in this work.

The results of antimalarial activity are shown in Table 5 and it was found that the derivatives of triphenyltin(IV) compounds showed the highest antimalarial activity in the series compared to the diphenyltin(IV) and dibutyltin(IV) derivatives ${ }^{18}$. Thus the number of carbon atoms present as well as the type of the ligands has a significant effect on the antimalarial activity of the organotin(IV) compounds tested $^{23}$.

The results also indicated that the organotin(IV) chlorobenzoate compounds synthesized exhibited much higher antimalarial activity compared to those of the ligands, starting materials and intermediate products. Thus, our results are consistent with a wellknown fact that many biologically active compounds become more active upon complexation than in their uncomplexed forms ${ }^{24}$. According to Crowe the actual biological activity of diorganotin compounds of the type RR'SnXY (R and R' = alkyl or aryl; $\mathrm{X}$ and $\mathrm{Y}=$ anions) is determined solely by the RR' $\mathrm{Sn}^{2+}$ moiety ${ }^{25}$.

Table 5. The $\mathrm{IC}_{50}$ of the compound tested.

\begin{tabular}{|c|c|}
\hline Compounds & IC $_{50}(\mu \mathrm{g} / \mathbf{m L})$ \\
\hline Chloroquine & $2.0 \times 10^{-3}$ \\
\hline$\left.\left[\left(\boldsymbol{n}-\mathbf{C}_{4} \mathbf{H}_{9}\right)_{2} \mathbf{S n}\left(\mathbf{O O C C}_{6} \mathbf{H}_{4} \mathbf{C l}\right)\right)_{2}\right](3)$ & $8.7 \times 10^{-2}$ \\
\hline$\left[\left(\mathbf{C}_{6} \mathbf{H}_{5}\right)_{2} \mathbf{S n}\left(\mathbf{O O C C}_{6} \mathbf{H}_{4} \mathbf{C l}\right)_{2}\right](6)$ & $9.7 \times 10^{-2}$ \\
\hline$\left.\left[\left(\mathbf{C}_{6} \mathbf{H}_{5}\right)_{3} \mathbf{S n}\left(\mathbf{O O O C C}_{6} \mathbf{H}_{4} \mathbf{C l}\right)\right](9)\right)$ & $3.1 \times 10^{-3}$ \\
\hline
\end{tabular}

\section{Conclusions}

We successfully prepared the organotin(IV) chlorobenzoate compounds. Based on the discussion, the compounds synthesizedy have shown some promising result to be used as antimalarial drug. The derivative of triphenyltin(IV) chlorobenzoate has again shown to be most active as antimalarial agent. This is perhaps in line with other data relating to the number of carbon atom present in the compound. We are now further examining the antimalarial activity of the compounds, and we will test based on Artemisin in Combination Therapy in order to find out the potential users of these compounds for the future antimalarial drug.

\section{Acknowledgements}

The authors are grateful to the Institute of Research and Community Services, Universitas Lampung and Directorate of Research and Community Services, The Ministry of Research, Technology and Higher Education, Indonesia, that provided fund for this project to be undertaken through Penelitian Dasar (Basic Research Grant Scheme) 2019 with contract number 857/UN26.21/PN/2019, April 8, 2019. Special thanks must go to Directorate of Intellectual
Property Right (DPKI), Directorate General of Strengthening Research and Development for giving SH support to present the paper in the international conference, International Conference on the Coordination and Organometallic Chemistry of Germanium, Tin and Lead (ICCOC-GTL) September 1-6, 2019 Saitama, Japan.

\section{Experimental}

\subsection{Materials}

All reagents used were $\mathrm{AR}$ grade. Dibutyltin(IV) dichloride $\quad\left(\left[\left(n-\mathrm{C}_{4} \mathrm{H}_{9}\right)_{2} \mathrm{Cl}_{2}\right]\right), \quad$ diphenyltin(IV) dichloride $\left(\left[\left(\mathrm{C}_{6} \mathrm{H}_{5}\right)_{2} \mathrm{Cl}_{2}\right]\right)$, triphenyltin(IV) chloride $\left(\left[\left(\mathrm{C}_{6} \mathrm{H}_{5}\right)_{3} \mathrm{Cl}\right]\right)$, chlorobenzoic acid, RPMI were obtained from Sigma, water HPLC grade, sodium hydroxide $(\mathrm{NaOH})$ and methanol $\left(\mathrm{CH}_{3} \mathrm{OH}\right)$ were JT Baker products, and were used without further purification.

\subsection{Characterization and instrumentations}

The UV spectra were recorded in the UV region and were measured using a UV- Shimadzu UV-245 Spectrophotometer. Measurements were performed in $1 \mathrm{~mL}$ quartz-cells. Solutions were prepared using methanol as the solvent with the concentration of 
$1.0 \times 10^{-4} \mathrm{M}$. Microelemental analyses (CHNS) were conducted using Fision EA 1108 series elemental analyser. IR spectra were measured in the range of 4000-400 $\mathrm{cm}^{-1}$ using a Bruker VERTEX 70 FT-IR spectrophotometer with $\mathrm{KBr}$ discs. ${ }^{1} \mathrm{H}$ and ${ }^{13} \mathrm{C}$ NMR spectra were obtained with a Bruker AV $600 \mathrm{MHz}$ NMR (600 MHz for ${ }^{1} \mathrm{H}$ and $150 \mathrm{MHz}$ for ${ }^{13} \mathrm{C}$ ). All experiments were run in $\mathrm{DMSO}^{-\mathrm{D}_{6}}$ at $298 \mathrm{~K}$. The number of runs used for ${ }^{1} \mathrm{H}$ experiments was 32 with reference at DMSO signal at $2.5 \mathrm{ppm}$, while the ${ }^{13} \mathrm{C}$ were 1000-4000 scans with the reference DMSO signal at $39.5 \mathrm{ppm}$.

5.3. Preparation of organotin(IV) chlorobenzoates The organotin(IV) chlorobenzoates used in this work were prepared based on the procedure previously reported ${ }^{10-13,16-18}$ and was adapted from the work by Szorcsik et al. ${ }^{3}$. An example procedure in the preparation of diphenyltin(IV) benzoate was as follows:

$3.44 \mathrm{~g}(0.01 \mathrm{~mol})\left[\left(\mathrm{C}_{6} \mathrm{H}_{5}\right)_{2} \mathrm{SnCl}_{2}\right]$ (1) in $50 \mathrm{~mL}$ methanol was added with solution of $0.8 \mathrm{~g}(0.02 \mathrm{~mol})$ $\mathrm{NaOH}$ in methanol. The reaction mixtures were stirred for about 60 minutes. Compound $\left[\left(\mathrm{C}_{6} \mathrm{H}_{5}\right)_{2} \mathrm{Sn}(\mathrm{OH})_{2}\right]$ (2) was precipitated out as white solid, filtered off and dried in vacuo till they are ready for analysis and further reaction. The yield was $2.92 \mathrm{~g}$ (95\%).

$0.4605 \mathrm{~g}(1.5 \mathrm{mmol})$ compound 2 in $50 \mathrm{~mL}$ of methanol was added with 2 mole equivalents of chlorobenzoic acid $(0.235 \mathrm{~g})$ and was refluxed for 4 hours at $60-62^{\circ} \mathrm{C}$. After removal of the solvent by rotary evaporator, the produced compounds $\left[\left(\mathrm{C}_{6} \mathrm{H}_{5}\right)_{2} \mathrm{Sn}\left(2-\mathrm{OOCC}_{6} \mathrm{H}_{4} \mathrm{Cl}\right)_{2}\right]$ were dried in vacuo until they are ready for analysis and further use for in vitro antimalarial activity. The yield was $1.67 \mathrm{~g}$ (it was more than $\sim 92 \%$ ).

A similar procedure was also adapted in the preparation of dibutyltin(IV) and triphenyltin(IV) derivatives, $\left[\left(n-\mathrm{C}_{4} \mathrm{H}_{9}\right)_{2} \mathrm{Sn}\left({ }_{2}-\mathrm{OOCC}_{6} \mathrm{H}_{4} \mathrm{Cl}\right)_{2}\right]$ (3) and $\left[\left(\mathrm{C}_{6} \mathrm{H}_{5}\right)_{3} \mathrm{Sn}\left(2-\mathrm{OOCC}_{6} \mathrm{H}_{4} \mathrm{Cl}_{2}\right)\right]$ (9), respectively. For triphenyltin(IV) only one mole equivalent of the chlorobenzoic acid was added.

\subsection{In vitro antimalarial bioactivity assays}

The in vitro antimalarial assays were done in the Institute of Tropical Disease, Universitas Airlangga, Surabaya Indonesia. The malaria parasite $P$. falciparum 3D7 clone was essentially propagated according to the previously published procedure ${ }^{2,19}$. Briefly, parasite cultures were propagated in tissue culture flasks containing RPMI-1640 medium supplemented with $25 \mu \mathrm{g} / \mathrm{mL}$ gentamycin, $50 \mu \mathrm{g} / \mathrm{mL}$ hypoxanthine, $25 \mathrm{mM}$ Hepes buffer, $25 \mathrm{mM}$ sodium bicarbonate, $10 \% \mathrm{AB}+$ human serum, $5 \%$ haematocrit and human erythrocytes with the $\mathrm{pH}$ maintained at 7.4. Each compound tested was first dissolved in DMSO and diluted to different concentration by adding complete malaria medium. Chloroquine was used as a positive control. To determine the antiplasmodial activity of each isolated compound, parasites were placed in a 24 -well culture plate in the presence of a wide concentration range of each compound. The parasite growth was monitored by making a blood smear that was fixed with methanol and stained with Giemsa. Total parasitaemia was calculated as the number of parasites-observed, divided by the total erythrocyte multiplied by $100 \%$. The concentration response parasite growth data were calculated by a linear regression provided by SYSTAT Sigma Plot, using the 50\% inhibitory concentration $\left(\mathrm{IC}_{50}\right)$. The $\mathrm{IC}_{50}$ value is defined as that concentration of compound producing $50 \%$ growth inhibition relative to untreated control.

\section{References}

1. A. A. James, Mosquito molecular genetics: the hands that feed bite back, Science, 1992, 257 (5066), 37-38. https://doi.org/10.1126/science.1352413.

2. P. N. Harijanto, Radical change on the malaria treatment in Indonesia, Cermin Dunia Ked., 2006, 152, 30-36.

3. WHO, Roll Back Malaria program. Available at. http://www.who.int/malaria/en/. 2011. [Verified 20 April 2011].

4. A. Szorcsik, L. Nagy, K. Gadja-Schrantz, L. Pellerito, E. Nagy, E. T. Edelmann, Structural studies on organotin(IV) complexes formed with ligands containing $\{\mathrm{S}, \mathrm{N}, \mathrm{O}\}$ donor atoms, $\mathrm{J}$ Radioanal Nucl Chem., 2002, 252 (3), 523-530. https://doi.org/10.1023/A:1015802820423.

5. E. R. T. Tiekink, Structural Chemistry of Organotin Carboxylates: a Review of the Crystallographic Literature, App Organomet Chem., 1991, 5 (1), 1-23. https://doi.org/10.1002/aoc.590050102.

6. K. Shahid, S. Ali, S. Shahzadi, Z. Akhtar, Organotin(IV) Complexes on Aniline Derivatives Part-II-Synthesis and Spectroscopic Characterization of Organotin(IV) Derivatives of 2-[4-Bromoanailine)carboxyl]benzoic Acid, Turk J Chem., 2003, 27, 209-215.

7. L. Pellerito, L. Nagy, Organotin(IV $)^{\mathrm{n}+}$ complexes formed with biologically active ligands: equilibrium and structural studies, and some biological aspects, Coord Chem Rev., 2002, 224 (1-2), 111-150. https://doi.org/10.1016/S0010-8545(01)00399-X.

8. B. Gleeson, J. Claffey, D. Ertler, M. Hogan, H. Müller-Bunz, F. Paradisi, D. Wallis, M. Tacke, Novel organotin antibacterial and anticancer drugs, Polyhedron, 2008, 27 (18), 3619-3624. https://doi.org/10.1016/j.poly.2008.09.009.

9. W. Rehman, A. Badshah, S. Khan, L. T. A. Tuyet, Synthesis, characterization, antimicrobial and antitumor screening of some diorganotin(IV) complexes of 2-[(9H-Purin-6-ylimino)]-phenol, Eur J Med Chem., 2009, 44 (10), 3981-3985. https://doi.org/10.1016/j.ejmech.2009.04.027. 
10. S. Hadi, M. Rilyanti, Synthesis and in vitro anticancer activity of some organotin(IV) benzoate compounds, Orient J Chem., 2010, 26 (3), 775-779.

11. S. Hadi, M. Rilyanti, Suharso, In Vitro Activity and Comparative Studies Of Some Organotin(IV) Benzoate Derivatives Against Leukemia Cancer Cell: L-1210, Indo J Chem., 2012, 12 (2), 172-177.

12. S. Hadi, B. Irawan, Efri, The Antifungal Activity Test of Some Organotin(IV) Carboxylates, J Appl Sci Res., 2008, 4 (11), 1521-1525.

13. S. Hadi, M. Rilyanti, Nurhasanah, Comparative Study on the Antifungal Activity of Some Diand Tributyltin(IV) Carboxylate Compounds, Modern Appl Sci., 2009, 3 (2), 12-17.

14. R. Singh, P. Chaudary, N. K. Khausik, A Review: Organotin Compounds in Corrosion Inhibition, Rev Inorg Chem., 2010, 30 (4), 275-294. https://doi.org/10.1515/REVIC.2010.30.4.275.

15. N. N. Hazani, Y. Mohd, S. A. I. S. M. Ghazali, Y. Farina, N. N. Dzulkifli, Electrochemical Studies on Corrosion Inhibition Behaviour of Synthesised 2-acetylpyridine 4-ethyl-3thiosemicarbazone and Its Tin(IV) Complex for Mild Steel in $1 \mathrm{M} \mathrm{HCl}$ Solution, J Electrochem Sci Technol., 2019, 10 (1), 29-36. https://doi.org/10.5229/JECST.2019.10.1.29.

16. H. Kurniasiah, M. Nurissalam, B. Iswantoro, H. Afriyani, H. I. Qudus, S. Hadi, The Synthesis, Characterization and Comparative Anticorrosion Study of Some Organotin(IV) 4Chlorobenzoates, Orient J Chem., 2015, 31 (4), 2377-2383. http://dx.doi.org/10.13005/ojc/310467.

17. S. Hadi, H. Afriyani, W. D. Anggraini, H. I. Qudus, T. Suhartati, The Synthesis and Potency Study of Some Dibutyltin(IV) Dinitrobenzoate Compounds as Corrosion Inhibitors for Mild Steel HRP in DMSO-HCl Solution, Asian J Chem., 2015, 27 (4), 1509-1512. https://doi.org/10.14233/ajchem.2015.18590.
18. S. Hadi, Noviany, M. Rilyanti, In Vitro Antimalarial Activity of Some Organotin(IV) 2Nitrobenzoate Compounds Against Plasmodium falciparum, Macedon J Chem Chem Eng., 2018, 37 (2), 185-191. https://doi.org/10.5229/JECST.2019.10.1.29.

19. C. Hansch, R. P. Verma, Larvicidal activities of some organotin compounds on mosquito larvae: A QSAR study, Eur J Med Chem., 2009, 44 (1), 260-273. https://doi.org/10.1016/j.ejmech.2008.02.040.

20. Sudjadi, The Structure Determination of Organic Compounds. Ghalia Publishers, 1985, pp. 45-51. (In Indonesian).

21. S. Hadi, T. G. Appleton, G. A. Ayoko, Reactions of $f a c$ - $\left[\mathrm{PtMe}_{2}(\mathrm{OMe})\left(\mathrm{H}_{2} \mathrm{O}\right)_{3}\right]^{+}$with halide ions: effect of halide trans effect on methoxide hydrolysis, Inorg Chim Acta, 2003, 352, 201-207. https://doi.org/10.1016/S0020-1693(03)00137-3.

22. S. Hadi, T. G. Appleton, Reactions of cisplatin hydrolytes, cis- $\left[\mathrm{Pt}\left({ }^{15} \mathrm{NH}_{3}\right)_{2}\left(\mathrm{H}_{2} \mathrm{O}\right)_{2}\right]^{2+}$, with $\mathrm{N}$ acetyl-L-cysteine, Russ J Inorg Chem., 2010, 55 (2), 223-228. https://doi.org/10.1134/S0036023610020142.

23. Z. H. Chohan, A. Rauf, Some Biologically Active Mixed Ligand Complexes of Co(II), $\mathrm{Cu}(\mathrm{II})$ and $\mathrm{Ni}(\mathrm{II})$ with $\mathrm{ONO}, \mathrm{NNO}$ and $\mathrm{SNO}$ Donor Nicotinoylhydrazine-Derived Ligands, Synth. React Inorg Met-Org Chem., 1996, 26, 591-604. https://doi.org/10.1080/00945719608004764.

24. H. Gershon, Antifungal Activity of Bischelates of 5-, 7-, and 5,7-halogenated 8-quinols with copper(II). Determination of the long and short access of the pores in the fungal spore wall, $\mathrm{J}$ Med Chem., 1974, 17, 824-827.

25. A. J. Crowe, The antitumour activity of tin compounds; in Gielen M., Ed. Metal-Based Drugs, 1989, 1, 103-149. https://doi.org/10.1007/978-3-642-74191-3_2. 